\title{
Effect of Foliar Application of Micronutrients on Antioxidants and Pungency in Onion
}

\author{
Manas DENRE ${ }^{1,4 *}$, Amitava BHATTACHARYA ${ }^{1}$, Srikumar PAL ${ }^{1}$, Arunabha \\ CHAKRAVARTY ${ }^{1}$, Arup CHATTOPADHYAY², Debasis MAZUMDAR ${ }^{3}$
}

\author{
IBidhan Chandra Krishi, Department of Agricultural Biochemistry, Viswavidyalaya, Mohanpur, 741252, Nadia, West Bengal, India \\ ${ }^{2}$ Bidhan Chandra Krishi, AICRP on Vegetable Crops, Directorate of Research, Viswavidyalaya, Mohanpur, 741252, Nadia, West Bengal, India \\ ${ }^{3}$ Bidhan Chandra Krishi, Department of Agricultural Statistics, Viswavidyalaya, Mohanpur, 741252, Nadia, West Bengal, India \\ ${ }^{4}$ Birsa Agricultural University, Ranchi Centre, ICAR-AICRP-MSPE, Department of Soil Science \& Agricultural Chemistry, Kanke, Ranchi-834006, Jharkhand, \\ India; manas.denre0803@gmail.com (*orrespondingauthor)
}

\begin{abstract}
The aim of the present work was to study the effect of foliar application of micronutrients [ $\mathrm{Zinc}$ : $\mathrm{Zn}_{1}(0 \%) ; \mathrm{Zn}_{2}(0.5 \%) ; \mathrm{Zn}_{3}(1.0 \%)$ and Boron: $\mathrm{B}_{1}(0 \%) ; \mathrm{B}_{2}(0.25 \%) ; \mathrm{B}_{3}(0.5 \%)$ ] on the antioxidants and pungency of onion cv. "Sukhsagar" (Allium cepa L.). In this experiment, it was suggested that the highest contents of total and free phenol was obtained by the highest dose of $\mathrm{Zn}(1 \%)$ in combination with $0 \% \mathrm{~B}$, and single dose of $\mathrm{Zn}(0.5 \%)$ in combination with $0 \% \mathrm{~B}$ respectively. The superoxide dismutase (SOD) activity was found to increase with respect to control following the highest dose of $\mathrm{B}(0.5 \%)$ alone. However, the peroxidase (POD) activity increased more with respect to control following the single dose of $\mathrm{B}(0.25 \%)$ rather than the double dose $(0.5 \%)$. The highest Molybdate reducing antioxidant potential (MRAP) was observed in $0.5 \% \mathrm{Zn}$ in combination with $0 \% \mathrm{~B}$, whereas that of 2, 2-Diphenyl- $\beta$-picrylhydrazyl radical scavenging activity (DPPHRAC) was found in the interaction effect of the double doses of both $\mathrm{Zn}(1 \%)$ and B (0.5\%), which also offered the lowest lipid peroxidation. The highest pyruvic acid development was observed by the interaction effect of $0 \% \mathrm{Zn}$ and $0.25 \% \mathrm{~B}$. Based on the average values of the biochemical parameters and the results of PCA, the treatment with $\mathrm{Zn}_{1} \mathrm{~B}_{3}(0 \%$ of $\mathrm{Zn}$ in combination with double dose of $0.5 \%$ of B) was proved to be most promising with respect to antioxidant properties.
\end{abstract}

Keywords: Allium cepa L., antioxidants, foliar application, micronutrients, pyruvic acid

\section{Introduction}

From time immemorial, onion (Allium cepa L.) has been used as common food and also for the treatment of many diseases. Apart from providing basic nutrition, onion is well known for its health benefits; numerous therapeutic properties have been reported in onion viz., anticarcinogenic, antibiotic, antibacterial, antifungal and antioxidant properties (Benkeblia, 2005). Antioxidants rich food play an important role in prevention of cardiovascular diseases and cancers (Garber $e t$ al., 2002), neurodegenerative diseases (Di Matteo and Esposito, 2003), as well as prevention of inflammation and problems causes by cell and cutaneous aging (Ames et al., 1993).

Micronutrients have received a great deal of importance in crop production during recent years because of the widespread occurrences of their deficiencies from different parts of the country. Researchers from almost all the states in the country have also reported significant responses of many crops to micronutrient fertilization. Zinc ( $\mathrm{Zn}$ ) and boron (B) is an essential trace element for plants, being involved in many enzymatic reactions and is necessary for their good growth and development. Some studies estimates indicate that a large number of diverse materials can serve as sources of plant nutrients. The majority of nutrient input to agriculture comes from commercial mineral fertilizers. Mineral fertilizers are considered to play a significant but lesser role in nutrient contribution, leaving aside their beneficial effects on soil physicochemical and biological properties. Foliar feeding is a relatively new and controversial technique of feeding plants by applying liquid fertilizer directly to their leaves.

Zinc $(\mathrm{Zn})$ is one of the essential micronutrients playing a significant role in many vital metabolic processes (Rout and Das, 2003; Aravind and Prasad, 2005a; Aravind and Prasad, 2005b). An increase in the level of reactive $\mathrm{O}_{2}$ species (ROS) may appear in $\mathrm{Zn}$-deficient plants. $\mathrm{Zn}$ deficiency enhances $\mathrm{O}_{2}{ }^{-}$ generation by enhancing NADPH-dependent oxidase activity (Cakmak, 2000). Moreover, as it is an integral constituent of $\mathrm{Cu} / \mathrm{Zn}$ superoxide dismutase $(\mathrm{Cu} / \mathrm{Zn} \mathrm{SOD}), \mathrm{Zn}$ play an important role in the detoxification of the $\mathrm{O}_{2}{ }^{--}$(Apel and Hirt, 2004). Besides $\mathrm{Zn}$ deficiency, increased in activity of POD (Kosesakal and Unal, 2009). Hajiboland and Amirazad (2010) also reported that under deficiency of $\mathrm{Zn}$ caused the activities of POX and CAT to decrease. Excess $\mathrm{Zn}$ can also affect the uptake of other nutrient elements. Thus, deficiency of the other elements may cause oxidative stress (del-Rio et al., 1991; Bonnet et al., 2000). These oxygen species are highly reactive 
374

and cause the death of plants by damaging membrane lipids, proteins, pigments and nucleic acids (Chaoui et al., 1997; Weckx and Clijsters, 1997; Bonnet et al., 2000; Cuypers et al., 2002).

There is evidence that $B$ is one of the nutrients responsible for the changes in concentration and a number of metabolic pathways such as carbohydrate metabolism, nitrogen metabolism, phenol metabolism and ascorbate metabolism in plants (Marschner, 1995; Dordas and Brown, 2005; Luaszewski and Blevins, 1996). In fact, it is well known that B deficiency causes an accumulation of phenolics through the stimulation of the enzyme phenylalanine-ammonium lyase (PAL) (Cakmak et al., 1995; Ruiz et al., 1998b; CamachoCristobal et al., 2002). Other reports have shown that $\mathrm{B}$ deficiency not only induced quantitative changes but also qualitative changes in the phenolic pool of plants (CamachoCristobal et al., 2002 Camacho-Cristobal et al., 2004; Karioti et al., 2006). However, B deprivation also increased the activity of polyphenol oxidase (PPO) (Pfeffer et al., 1998; CamachoCristobal et al., 2002), enzyme that catalyses the oxidation of phenolic compounds into quinones. Besides yield increase a relationship also exists between vitamin $\mathrm{C}$ content and boron treatment in different vegetables like summer squash, beet, tomato and potato (Luaszewski and Blevins, 1996; Govindan et al., 1950; Mondy and Mucshi, 1993).

Aerobic organisms are constantly exposed to one or more systems that generate reactive oxygen species (ROS), including the superoxide radical anion $\left(\mathrm{O}_{2}{ }^{-}\right)$, hydroxyl radical $\left({ }^{\circ} \mathrm{OH}\right)$, hydrogen peroxide $\left(\mathrm{H}_{2} \mathrm{O}_{2}\right)$, various peroxyl radicals ( $\left.\mathrm{ROO}{ }^{*}\right)$, and singlet oxygen $\left({ }^{1} \mathrm{O}_{2}\right)$. These ROS are highly reactive and can damage living cells if formed in significant amounts. To avoid cellular damage by ROS, most biological systems have developed defense mechanisms, antioxidants that convert ROS to unreactive derivatives. Recently, Denre et al. (2011) reported that the onion is rich in antioxidants. The authors also concluded that the green pungent pepper contains a few chain breaking antioxidants (e.g. Vitamin $\mathrm{C}$ and phenolics etc. that scavenge oxygen radicals and thereby break radical chain sequences) and few preventive antioxidants (e.g. SOD, POD and CAT etc. which prevent or inhibit the formation of ROS). Therefore, the aim of the present study was to investigate the effects of foliar application of micronutrients ( $\mathrm{Zn}$ and $\mathrm{B}$ ) with respect to level of antioxidant constituents and antioxidant activities along with pyruvic acid development of onion in order to identify the best treatment that could be used to develop improved quality.

\section{Materials and Methods}

\section{Field experiment}

The seedling was grown in nursery beds prepared in a sandy loam soil. The beds were $1.5 \mathrm{~m}$ long and $1.0 \mathrm{~m}$ wide. Weathered cow dung manure, $4 \mathrm{~kg} \mathrm{~m}^{-2}$, was mixed into the beds. Beds were drenched with formaldehyde (4\%) and covered with polythene sheets for ten days to avoid damping off disease. Seedling was treated with Thiram $\left(3 \mathrm{~g} \mathrm{~kg}^{-1}\right.$ of seed) (Gujarat Pesticides Private Limited, Gandhinagar, Gujarat, India) prior to sowing. Onion seeds of the cv. 'Sukhsagar' the most popular cultivar in West Bengal was obtained from AICRP on Vegetable Crops and were sown at $0.5 \mathrm{~cm}$ depth and $5 \mathrm{~cm}$ apart and covered with finely sieved leaf mold. After sowing, beds were covered with straw until germination and hand watered regularly. Seedlings were raised as before and hardened by withholding water 4 days before transplanting.

The main field was of sandy loam soil. Land preparation was done with 3-4 ploughings and beds were prepared. Fertilizer at the rate of $60 \mathrm{~N}-60 \mathrm{P}-60 \mathrm{~K} \mathrm{~kg} \mathrm{ha}{ }^{-1}$ was applied before transplanting and incorporated well into the soil. The source of nitrogen $(\mathrm{N})$ was urea, that of phosphate $(\mathrm{P})$ was single superphosphate and Potash $(\mathrm{K})$ was from muriate of potash. Additional nitrogen fertilizer at the rate of $60 \mathrm{~N} \mathrm{~kg} \mathrm{ha}^{-1}$ was applied 21 days after transplanting. The 40 days old seedlings were transplanted on muddy flat surface soil in $5 \mathrm{~cm}$ deep furrows with $15 \mathrm{~cm}$ spacing between rows and $10 \mathrm{~cm}$ within plants in plots. The plot size was $2.25 \mathrm{~m} \times 2.0 \mathrm{~m}$. The experiment consisting of nine treatments including control (only water sprayed) were arranged in a factorial randomized block design with three replications of each treatment at the In-check Research Farm, Bidhan Chandra Krishi Viswavidyalaya, Kalyani, Nadia, West Bengal, India. The detail treatments are summarized in Table 1.

As because onion is a shallow rooted crop, supplementary irrigations (12 weekly irrigations providing approximately $5 \mathrm{~cm}$ of water were applied with the first being before transplanting) were given. There were four light hoeings within 9 weeks of transplanting. The application of fungicide Chlorothalonil at $2 \mathrm{~g}$ $\mathrm{L}^{-1}$ with sticker Sandovit at $1 \mathrm{ml} \mathrm{L}^{-1}$ was applied four to five times beginning 15 days after transplanting and at 15 days intervals to control purple blotch disease [Alternaria porri (Ellis) Cif].

Onion bulbs from each plot were harvested at 127-128 days after transplanting (when more than $80 \%$ plant leaves were dried). Sample (15-20 pieces of bulbs) from each plot was collected after harvesting. Fresh materials were washed, dried with soft tissue, and chopped with a sharp knife into small pieces before analysis of the content of non-enzymatic antioxidants, activity of enzymatic antioxidants and antioxidant activity under different systems of assay [molybdate reducing antioxidant potential (MRAP), DPPH radical scavenging activity and lipid peroxidation] as well as pyruvic acid development $(\mathrm{PAD})$ which is a measure of pungency.

\section{Chemical analysis}

Non-enzymatic antioxidants

Analysis of ascorbic acid content (AAC)

One gram of finely chopped onion tissue was extracted with $20 \mathrm{ml}$ of $4 \%$ oxalic acid following maceration in a pestle and mortar and the material centrifuged for $30 \mathrm{~min}$ at $10,000 \mathrm{~g}$. Ascorbic acid content was determined using the dichlorophenol indophenol titration procedure (Casanas et al., 2002). (FPC)

Analysis of total phenol content (TPC) and free phenol content

Total phenol was extracted in $50 \%$ methanolic $1.2 \mathrm{~N} \mathrm{HCl}$ and Free phenol was extracted in $50 \%$ aqueous methanol by boiling one gram of finely chopped tissue for $1.5 \mathrm{~h}$ at $80-90^{\circ} \mathrm{C}$ following the method of Vinson et al. (1995) and subsequent analysis was with the Folin-Ciocalteau reagent using Gallic acid as standard.

\section{Enzymatic antioxidants}

\section{Analysis of super oxide dismutase activity (SOD)}

One gram finely chopped bulb tissue extracts to inhibit photochemical reduction of nitroblue tetrazolium (NBT) in riboflavin light NBT system (Beauchamp and Fridovich, 1971) 


\begin{tabular}{ccc}
\hline Table 1. Different doses of micronutrients $(\mathrm{Zn}$ and $\mathrm{B})$ used as foliar spray for onion & Boron $(\mathrm{B})(\%)$ \\
\hline Treatments & Zinc $(\mathrm{Zn})(\%)$ & 0.0 \\
$\mathrm{~T}_{1}\left(\mathrm{Zn}_{1} \mathrm{~B}_{1}\right)$ & 0.0 & 0.0 \\
$\mathrm{~T}_{2}\left(\mathrm{Zn}_{1} \mathrm{~B}_{2}\right)$ & 0.0 & 0.25 \\
$\mathrm{~T}_{3}\left(\mathrm{Zn}_{1} \mathrm{~B}_{3}\right)$ & 0.5 & 0.5 \\
$\mathrm{~T}_{4}\left(\mathrm{Zn}_{2} \mathrm{~B}_{1}\right)$ & 0.5 & 0.0 \\
$\mathrm{~T}_{5}\left(\mathrm{Zn}_{2} \mathrm{~B}_{2}\right)$ & 0.5 & 0.25 \\
$\mathrm{~T}_{6}\left(\mathrm{Zn}_{2} \mathrm{~B}_{3}\right)$ & 1.0 & 0.5 \\
$\mathrm{~T}_{7}\left(\mathrm{Zn}_{3} \mathrm{~B}_{1}\right)$ & 1.0 & 0.0 \\
$\mathrm{~T}_{8}\left(\mathrm{Zn}_{3} \mathrm{~B}_{2}\right)$ & 1.0 & 0.25 \\
$\mathrm{~T}_{9}\left(\mathrm{Zn}_{3} \mathrm{~B}_{3}\right)$ & 0.5 & \\
\hline
\end{tabular}

Where, the source of $\mathrm{Zn}$ was supplied from $\mathrm{ZnSO}_{2} .7 \mathrm{H}_{2} \mathrm{O}$, and $\mathrm{B}$ from $\mathrm{Na}_{2} \mathrm{~B}_{4} \mathrm{O}_{7} .10 \mathrm{H}_{2} \mathrm{O}$. Each spraying was done four times with sticker starting from 30 days after transplanting and subsequent ones at an interval of 10 days during vegetative stage.

was used to determine SOD activity. Absorbance at $560 \mathrm{~nm}$ was recorded and percentage inhibitory activity was calculated as $\left[\left(\mathrm{A}_{0}-\mathrm{A}_{\mathrm{e}}\right) / \mathrm{A}_{0}\right] \times 100$ where $\mathrm{A}_{0}=$ absorbance without extract and $A_{e}=$ absorbance with extract.

\section{Analysis of peroxidase activity (POD)}

One gram of freshly harvested onion tissue from each treatment was macerated in a pestle and mortar and extracted with $10 \mathrm{ml}$ tris-HCL buffer $(\mathrm{pH} 7.6)$ to determine POD activity. Triturated samples were centrifuged at $10,000 \mathrm{~g}$ for 30 min at $4^{\circ} \mathrm{C}$ and supernatants were assessed for enzyme activity. The POD was estimated by mixing $0.1 \mathrm{ml}$ chilled enzyme extract with $2.8 \mathrm{ml}$ reaction mixture $(0.5 \%$ o-dianisidine dissolved in methanol, $0.28 \mathrm{ml} \mathrm{Na}$-acetate buffer, $2.4 \mathrm{ml}$ water). The reaction was initiated by adding $0.1 \mathrm{ml} \mathrm{H}_{2} \mathrm{O}_{2}$ (30\%). Changes in absorbance at $430 \mathrm{~nm}$ were monitored at $1 \mathrm{~min}$ intervals for up to $3 \mathrm{~min}$. POD activity was measured using $o$ dianisidine as the substrate (Bhattacharya et al., 2010) and expressed as $\mathrm{mM}$ o-dianisidine oxidized $\bullet \mathrm{min}^{-1} \bullet^{-1}$ of fresh tissue using the extinction coefficient $1.13 \times 10^{4} \bullet \mathrm{M}^{-1} \bullet \mathrm{cm}^{-1}$.

\section{Analysis of catalase activity $(C A T)$}

An assay mixture of $3 \mathrm{ml}$ of phosphate buffer, $2 \mathrm{ml}$ of $\mathrm{H}_{2} \mathrm{O}_{2}$, and $1 \mathrm{ml}$ of enzyme source were pipette into a porcelain crucible and incubated for $1 \mathrm{~min}$ at $20^{\circ} \mathrm{C}$ to estimate CAT activity. The

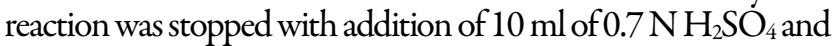
the reaction mixture titrated against $0.01 \mathrm{~N} \mathrm{KMnO}_{4}$ to determine residual $\mathrm{H}_{2} \mathrm{O}_{2}$ until a faint pink color that persisted for at least $15 \mathrm{~s}$. One unit of CAT activity was defined as amount of enzyme that destroyed $1 \mu \mathrm{mol}$ of $\mathrm{H}_{2} \mathrm{O}_{2} \bullet \mathrm{min}^{-1} \bullet \mathrm{g}^{-1}$ of fresh tissue. Changes in activity were measured using the method of Kar and Mishra (1976).

\section{Antioxidant activity}

Analysis of total antioxidant activity

A 0.5 gram freshly chopped onion tissue was extracted by macerating with $10 \mathrm{ml}$ distilled water for estimation of total antioxidant activity. Tubes containing extract and reagent solution (0.6 M sulfuric acid, $28 \mathrm{mM}$ sodium phosphate, and 4 $\mathrm{mM}$ ammonium molybdate) were incubated at $95^{\circ} \mathrm{C}$ for 90 min. After incubation the mixture cooled to room temperature, absorbance of each solution was measured at $695 \mathrm{~nm}$ against a blank (Prieto et al., 1999). Antioxidant capacity was expressed as gallic acid $(\mathrm{mg} / \mathrm{g})$ equivalent.

Analysis of 2, 2-Diphenyl- $\beta$-picrylhydrazyl radical scavenging activity (DPPHRAC)

The scavenging effect of onion for stable 2, 2-diphenyl- $\beta$ - picrylhydrazyl (DPPH) radical was monitored according to the method of Braca et al. (2001). One gram of fresh, finely chopped onion tissue was extracted with $10 \mathrm{ml}$ distilled water. A $0.2 \mathrm{ml}$ aqueous extract was added to $6 \mathrm{ml}$ of a $0.004 \%$ methanolic solution of DPPH. Absorbance at $517 \mathrm{~nm}$ was recorded after 30 min and percentage inhibitory activity was calculated as $\left[\left(\mathrm{A}_{0}-\right.\right.$ $\left.\left.\mathrm{A}_{\mathrm{e}}\right) / \mathrm{A}_{0}\right] \times 100$ where $\mathrm{A}_{0}=$ absorbance without extract and $\mathrm{A}_{\mathrm{e}}=$ absorbance with extract.

\section{Analysis oflipidperoxidation (LP)}

Lipid peroxidation was measured as the amount of malondialdehyde (MDA) produced by the thiobarbituric acid (TBA) reaction as described by Dhindsa et al. (1981). A one gram sample of chopped fresh onion tissue was homogenized in $2 \mathrm{ml}$ of $20 \%$ trichloroacetic acid (TCA) followed by centrifugation at $5,000 \mathrm{~g}$. A $20 \%$ TCA solution containing $0.5 \%$ TBA and 4\% butylated hydroxytoluene was added to a $1 \mathrm{ml}$ aliquot before heating at $95^{\circ} \mathrm{C}$ for $30 \mathrm{~min}$ and then cooling in an ice bath. The contents were centrifuged at $10,000 \mathrm{~g}$ and absorbance read at $532 \mathrm{~nm}$. The concentration of MDA was calculated using an extinction coefficient of $155 \bullet \mathrm{mM}^{-1} \bullet \mathrm{cm}^{-1}$.

\section{Analysis of pyruvic acid development (PAD)}

Pungency of onion bulbs was determined as pyruvic acid (Schwimmer and Weston, 1961; Anthon and Barrett, 2003). Pyruvic acid concentration was determined using the method of Schwimmer and Weston (1961). A one gram sample of each genotype was crushed in a pestle and mortar and incubated with 2, 4-dinitrophenylhydrazine and the absorbance read at $420 \mathrm{~nm}$ on a spectrophotometer for total pyruvic acid concentration, determined against a sodium pyruvate standard curve.

\section{Statistical analyses}

Data were subjected to ANOVA of a factorial randomized block design and by Duncan's multiple range tests, to determine differences among means. Principal component analysis (PCA), as the method of identifying the factor dimension of the data, was used to summarize the treatment informing in a reduced number of factors for selection of the best performing treatment. Statistical analyses were done using SPSS Professional Statistics ver.7.5 (SPSS Inc., Irvine, California).

\section{Results and Discussion}

Non-enzymatic antioxidants

Ascorbic acid and phenol

Boron application is known to elevate the ascorbate concentration in plant tissues as compared to B-deficient 
376

conditions (Blevins and Lukazewski, 1998). Increased ascorbate concentration by foliar applications of B was reported in potato (Mondy and Munshi, 1993). Keles et al. (2004) observed a significant rise in ascorbate level in orange under conditions of excess B. In our experiment neither $\mathrm{Zn}$ nor $\mathrm{B}$ application could produce any significant effect on AAC (Table 2). However, AAC increased, though not significantly, in both $\mathrm{Zn}$ and $\mathrm{B}$ treatments alone than the untreated controls $\left(\mathrm{Zn}_{1}\right.$ and $\left.B_{1}\right)$. The highest $A A C$ was obtained in the combination $\mathrm{Zn}_{3} \mathrm{~B}_{2}$ followed by $\mathrm{Zn}_{2} \mathrm{~B}_{3}$.

In contrast to AAC, the phenol contents were significantly different among the treatments. TPC, following $\mathrm{Zn}$ application alone, produced significantly higher value in $\mathrm{Zn}_{3}$ compared to control $\left(\mathrm{Zn}_{1}\right)$. In case of FPC, $\mathrm{Zn}_{2}$ alone produced significantly higher value as compared to $Z_{n_{1}}$ and $Z_{n}$, both of which produced no significant differences between their corresponding values. In $B$ treatments alone, TPC decreased with increasing doses of $\mathrm{B}$ producing significantly different values between $B_{1}$ and $B_{2}$. The values of TPC exhibited by $\mathrm{B}_{2}$ and $\mathrm{B}_{3}$ were not significantly different. A decreasing trend in FPC values with respect to control was also observed. The values of FPC significantly decreased in $\mathrm{B}_{2}$ while it increased significantly in $\mathrm{B}_{3}$. However, the value of FPC in latter was quite less than the control $\left(B_{1}\right)$. The decrease in phenols effectuated by $\mathrm{B}$ application supports the fact that phenols accumulate under conditions of B deficiency (Marschner, 1995). The highest TPC was obtained in $\mathrm{Zn}_{3} \mathrm{~B}_{1}$ whereas the highest $F P C$ was obtained in $\mathrm{Zn}_{2} \mathrm{~B}_{1}$.

\section{Enzymatic antioxidants \\ $S O D, P O D$ and $C A T$}

Among the antioxidative enzymes, SOD and CAT exhibited values, which are not significantly different. However, SOD activity increased in $\mathrm{Zn}_{2}$ following a decrease in $\mathrm{Zn}_{3}$ with respect to control, whereas the trend was reverse in $\mathrm{B}_{2}$ and $\mathrm{B}_{3}$ respectively. There are reports in favour of increase in SOD activity following application of excessive B (Garcia et al., 2001; Molassiotis et al., 2006; Cervilla et al., 2007). In case of CAT both $\mathrm{Zn}$ and $\mathrm{B}$ treatments alone resulted in almost similar values and the same trend of increase in single dose followed by a decrease in the double dose. The treatments $\mathrm{Zn}_{2} \mathrm{~B}_{1}$ and $\mathrm{Zn}_{2} \mathrm{~B}_{2}$ exhibited the highest SOD and CAT activities respectively. $\mathrm{Zn}$ is supposed to increase SOD and CAT activity (Luo et al., 2010) in Jatropha seedlings upto certain concentrations of $\mathrm{Zn}$. The CAT activity in response to B application varies according to plant species e.g., while increased B concentration reduced CAT activity in citrus (Keles et al., 2004), it induced the activity of this enzyme in sunflower (Dube et al., 2000), grapevine (Gunes et al., 2006) and tomato (Cervilla et al., 2007).

Single dose of $\mathrm{Zn}$ alone resulted in no significant differences in POD activity with respect to control, whereas the double dose $\left(\mathrm{Zn}_{2}\right)$ significantly decreased the POD activity, which is contrary to the observation that POD activity in Jatropha seedlings was induced gradually by increasing $\mathrm{Zn}$ concentrations (Luo et al., 2010). In case of $\mathrm{B}$ treatments alone, the POD activity increased significantly with respect to control, but more increment was observed in $\mathrm{B}_{2}$ (single dose) rather than $\mathrm{B}_{3}$ (double dose). This observation on POD activity conforms to the report of Molassiotis et al. (2006), who also noticed an increase in POD activity in leaves of apple rootstocks under high $B$.

\section{Antioxidant activity \\ MRAP, DPPHRAC and LP}

The MRAP values under $\mathrm{Zn}$ alone showed an increase in $\mathrm{Zn}_{1}$ followed by a decrease in $\mathrm{Zn}_{2}$ with respect to control. However, the differences were not significant. In case of $B$ alone the values assumed a clear significantly decreasing trend with respect to control. A similar trend was observed in case of total phenol content, which reinforces the fact that phenols contribute largely to MRAP assay. The maximum value of MRAP was observed in $\mathrm{Zn}_{2} \mathrm{~B}_{1}$.

The DPPHRAC assay revealed significantly increasing scavenging activity under different doses of $\mathrm{Zn}$ alone with respect to control. As because ascorbate contributes largely to DPPHRAC assay, a similar trend like AAC was observed in this assay. In case of $B$ application alone, however, the scavenging activity decreased significantly in $\mathrm{B}_{2}$ and increased significantly in $\mathrm{B}_{3}$. The highest DPPHRAC (lowest $\mathrm{IC}_{50}$ value) was observed in the treatment $\mathrm{Zn}_{3} \mathrm{~B}_{3}$.

The values of $L P$ are actually the values of concentrations of MDA produced by lipid peroxidation. Under $\mathrm{Zn}$ treatments alone, the value of $L P$ increased significantly in $\mathrm{Zn}_{2}$, while that decreased significantly in $\mathrm{Zn}_{3}$ than that of control $\mathrm{Zn}_{1}$. In $\mathrm{B}$ application alone, there was no significant differences between the values of $B_{2}$ and $B_{3}$, but the values showed an increasing trend. However, these values were significantly lower than that of the control $\left(B_{1}\right)$. Increase in MDA concentration in relation to excess B application was observed in apple rootstock (Molassiotis et al., 2006), grape (Gunes et al., 2006) and tomato (Cervilla et al., 2007). The highest MDA concentration was exhibited by the combination $\mathrm{Zn}_{2} \mathrm{~B}_{1}$.

\section{Pungency \\ $P A D$}

$\mathrm{PAD}$, under $\mathrm{Zn}$ treatments alone, produced significantly lower values than the control, though there were no significant differences between the PAD values exhibited by $Z_{2}$ and $Z n_{3}$. Again, the $B$ applications alone led to values with no significant differences between them. However, the values were higher than the control $\left(\mathrm{B}_{1}\right)$ and decreased in the double dose $\left(\mathrm{B}_{3}\right)$ than that of the single dose $\left(B_{2}\right)$. The highest PAD was observed in the treatment $\mathrm{Zn}_{1} \mathrm{~B}_{2}$.

\section{Principal component analysis (PCA)}

In this experiment also PCA was used to summarize the treatment information in a reduced number of components, where a total of three components were chosen (PC1, PC2 and PC3) due to their Eigen value being greater than 1.0 and they together explained $76 \%$ of total variance (Table 3 ).

The first component alone explained $34 \%$ of total variance where all the variables other than TPC and SOD are positively loaded meaning that all other variables restrict TPC and SOD, in which the former is not desirable. The positive loading of DPPHRAC and LP is also not desirable. Therefore, on the basis of the first component, the treatments $Z_{1} B_{2}, Z_{1} B_{3}, Z_{n} B_{1}$ etc. can 
Table 2. Effect of $\mathrm{Zn}$ and $\mathrm{B}$ on antioxidants content and antioxidant activity along with pyruvic acid development in onion

\begin{tabular}{|c|c|c|c|c|c|c|c|c|c|c|}
\hline Treatment & $\begin{array}{c}\text { AAC } \\
(\mathrm{mg} / 100 \mathrm{~g})\end{array}$ & $\begin{array}{c}\text { TPC } \\
(\mathrm{mg} / 100 \mathrm{~g} \\
\mathrm{GAE})\end{array}$ & $\begin{array}{c}\text { FPC } \\
(\mathrm{mg} / 100 \mathrm{~g} \\
\mathrm{GAE})\end{array}$ & $\begin{array}{l}\text { SOD } \\
\left(\mathrm{IC}_{50}\right. \\
\mathrm{mg} / \mathrm{ml})\end{array}$ & $\begin{array}{c}\text { POD } \\
\text { (mM } \\
o \text {-dianisidine } \\
\text { oxidized } / \mathrm{g} / \mathrm{min} \text { ) } \\
\end{array}$ & $\begin{array}{l}\text { CAT } \\
\text { (units) }\end{array}$ & $\begin{array}{r}\text { MRAP } \\
(\mathrm{mg} / \mathrm{g} \\
\mathrm{GAE})\end{array}$ & $\begin{array}{c}\text { DPPHR } \\
\text { AC } \\
\text { (IC } \text { IC: }_{50} \\
\mathrm{mg} / \mathrm{ml}) \\
\end{array}$ & $\begin{array}{c}\mathrm{LP} \\
(\mathrm{nmol} / \\
100 \mathrm{~g})\end{array}$ & $\begin{array}{c}\mathrm{PAD} \\
(\mu \mathrm{mol} / \mathrm{g})\end{array}$ \\
\hline \multicolumn{11}{|l|}{$\mathrm{Zn}_{\mathrm{n}}$} \\
\hline 1 & 12.52 & $112.60 \mathrm{~b}^{a}$ & $48.76 b$ & 5.12 & $0.33 a$ & 1.04 & 41.12 & $15.18 \mathrm{a}$ & $54.56 b$ & $10.62 \mathrm{a}$ \\
\hline 2 & 13.47 & $113.35 \mathrm{~b}$ & $60.52 a$ & 4.80 & $0.33 a$ & 1.06 & 41.96 & $11.63 b$ & $60.00 \mathrm{a}$ & $8.74 \mathrm{~b}$ \\
\hline 3 & 13.71 & $123.13 a$ & $51.67 \mathrm{~b}$ & 5.00 & $0.29 b$ & 0.96 & 40.32 & $10.44 \mathrm{c}$ & $45.89 \mathrm{c}$ & $8.31 \mathrm{~b}$ \\
\hline \multicolumn{11}{|l|}{ B } \\
\hline 1 & 12.29 & $126.23 a$ & $68.24 a$ & 4.79 & $0.27 \mathrm{c}$ & 1.03 & $48.95 a$ & $11.73 b$ & $58.11 \mathrm{a}$ & 8.81 \\
\hline 2 & 13.71 & $113.34 \mathrm{~b}$ & $42.78 c$ & 5.16 & $0.36 \mathrm{a}$ & 1.08 & $37.49 \mathrm{~b}$ & $15.58 \mathrm{a}$ & $50.78 \mathrm{~b}$ & 9.54 \\
\hline 3 & 13.71 & $109.51 \mathrm{~b}$ & $49.92 b$ & 4.97 & $0.31 b$ & 0.96 & $36.96 \mathrm{~b}$ & $9.94 \mathrm{c}$ & $51.56 \mathrm{~b}$ & 9.31 \\
\hline \multicolumn{11}{|l|}{$\mathrm{Zn}_{1}$} \\
\hline $\mathrm{B}_{1}$ & 11.34 & 122.46 & 49.67 & 5.04 & 0.14 & 0.98 & 31.88 & 12.18 & 49.67 & 8.04 \\
\hline $\mathrm{B}_{2}$ & 13.47 & 116.57 & 49.36 & 4.87 & 0.42 & 1.10 & 46.15 & 21.05 & 53.00 & 13.31 \\
\hline $\mathrm{B}_{3}$ & 12.76 & 98.76 & 47.24 & 5.44 & 0.43 & 1.06 & 45.32 & 12.32 & 61.00 & 10.51 \\
\hline \multicolumn{11}{|l|}{$\mathrm{Zn}_{2}$} \\
\hline$\overline{B_{1}}$ & 13.47 & 101.72 & 92.94 & 3.70 & 0.37 & 1.07 & 73.65 & 9.83 & 73.00 & 9.41 \\
\hline $\mathrm{B}_{2}$ & 12.05 & 118.23 & 40.84 & 5.40 & 0.45 & 1.11 & 24.53 & 14.73 & 54.33 & 7.42 \\
\hline $\mathrm{B}_{3}$ & 14.90 & 120.10 & 47.77 & 5.30 & 0.18 & 1.01 & 27.70 & 10.33 & 52.67 & 9.38 \\
\hline \multicolumn{11}{|l|}{$\mathrm{Zn}_{3}$} \\
\hline $\mathrm{B}_{1}$ & 12.05 & 154.51 & 62.11 & 5.62 & 0.31 & 1.06 & 41.32 & 13.18 & 51.67 & 8.99 \\
\hline $\mathrm{B}_{2}$ & 15.60 & 105.21 & 38.15 & 5.22 & 0.23 & 1.02 & 41.78 & 10.97 & 45.00 & 7.89 \\
\hline $\mathrm{B}_{3}$ & 13.47 & 109.66 & 54.75 & 4.16 & 0.33 & 0.80 & 37.84 & 7.17 & 41.00 & 8.04 \\
\hline
\end{tabular}

Analysis of variance ( $F$ values)

\begin{tabular}{|c|c|c|c|c|c|c|c|c|c|c|}
\hline $\mathrm{Zn}$ & NS & $4.968^{\circ}$ & $14.444^{\prime \prime}$ & NS & $16.384 "$ & NS & NS & $49.422^{*}$ & $35.378^{\prime \prime}$ & $26.650^{\prime \prime}$ \\
\hline B & NS & $11.053^{*}$ & $66.387^{\prime \prime}$ & NS & $60.946^{\circ}$ & NS & $8.551^{* *}$ & $67.497^{\circ}$ & $11.335^{\prime \prime}$ & NS \\
\hline $\mathrm{ZnXB}$ & NS & $18.420^{\circ}$ & $27.947^{\prime \prime}$ & $16.389^{\prime \prime}$ & $212.329 "$ & NS & 21.311" & $23.529^{\circ}$ & $16.500^{\prime \prime}$ & $24.093^{\prime \prime}$ \\
\hline
\end{tabular}

"significant at $5 \%,{ }^{* *}$ significant at $1 \%$, NS - non significant
${ }^{a}$ Values followed by the same letter in a column are not significant at $P<0.05$, Duncan's Multiple Range Test (DMRT)

Table 3. Results of principal component analysis (PCA) for effect of $\mathrm{Zn}$ and $\mathrm{B}$ on antioxidants content and antioxidant activity along with pyruvic acid development in onion

\begin{tabular}{|c|c|c|c|}
\hline Principle component & Eigen value & \% variance & \% Cumulative variance \\
\hline \multicolumn{4}{|c|}{ Eigen values and variance accounted for (\%) by PCA based on correlation matrix } \\
\hline 1 & 3.40 & 34.01 & 34.01 \\
\hline 2 & 2.73 & 27.27 & 61.28 \\
\hline 3 & 1.43 & 14.33 & 75.61 \\
\hline Variance & PC1 & PC2 & PC3 \\
\hline \multicolumn{4}{|c|}{ Factor loadings due to PCs with Eigen values greater than 1} \\
\hline Ascorbic acid & 0.02 & -0.34 & 0.77 \\
\hline Total Phenol(GAE) & -0.40 & 0.36 & -0.65 \\
\hline Free Phenol(GAE) & 0.80 & -0.32 & -0.45 \\
\hline SOD & -0.64 & 0.63 & -0.01 \\
\hline POD & 0.52 & 0.44 & 0.11 \\
\hline CAT & 0.36 & 0.78 & -0.01 \\
\hline MRAP(GAE) & 0.91 & -0.21 & -0.01 \\
\hline DPPHRAC & 0.11 & 0.91 & 0.15 \\
\hline LP & 0.86 & 0.16 & -0.19 \\
\hline PAD & 0.48 & 0.54 & 0.38 \\
\hline
\end{tabular}

be selected as having all desirable traits (Fig. 1).

PC2, on the other hand, explained another $27 \%$ of total variance in which AAC, FPC, and MRAP are negatively loaded as opposed by all other variables which are positively loaded. But positive loading of SOD, DPPHRAC, and LP is not desirable. So, considering PC2, the performing treatments would be $\mathrm{Zn}_{1} \mathrm{~B}_{3}, \mathrm{Zn}_{2} \mathrm{~B}_{3}$ and $\mathrm{Zn}_{3} \mathrm{~B}_{2}$.

PC3 explained an additional $14 \%$ of total variance in which AAC, POD, DPPHRAC and PAD restrict the values of TPC, FPC, and LP. Considering PC3 the performing treatment combinations are $\mathrm{Zn}_{1} \mathrm{~B}_{3}, \mathrm{Zn}_{3} \mathrm{~B}_{3}$, $\mathrm{Zn}_{2} \mathrm{~B}_{2}$ (Fig. 2). 


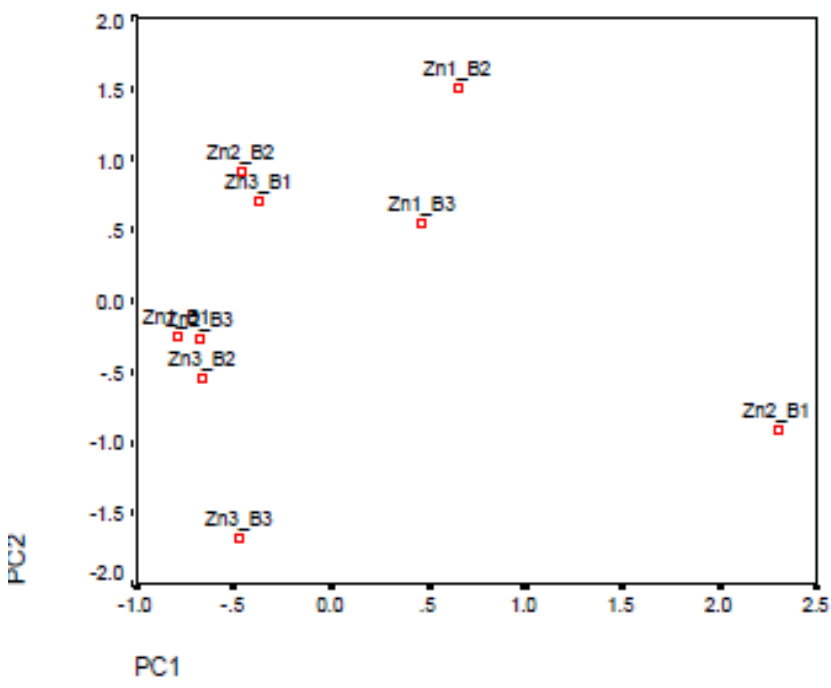

Fig. 1. Scatter diagram of the regression factor scores for the first and second components produced by PCA

\section{Conclusions}

Considering all the parameters and the results of three principal component analyses it can be suggested that the promising treatment combination for onion crop might be $\mathrm{Zn}_{1} \mathrm{~B}_{3}$ followed by $\mathrm{Zn}_{3} \mathrm{~B}_{3}$, and $\mathrm{Zn}_{2} \mathrm{~B}_{3}$, which may bring about the proper value addition by enhancing the antioxidants content and antioxidant activity along with pungency development.

\section{Acknowledgements}

The authors would like to thank the Bidhan Chandra Krishi Viswavidyalaya for supporting the hereby work.

\section{References}

Ames BM, Shigenaga MK Hagen TM (1993). Oxidants, antioxidants and the degenerative diseases of aging. Proceedings of the National Academy of Science 90(17):7915-7922.

Apel K, Hirt H (2004). Reactive oxygen species: metabolism oxidative stress and signaling transduction. Annual Review of Plant Biology 55:373-399.

Aravind P, Prasad MNV (2005b). Cadmium-Zinc interactions in hydroponic system using Ceratophyllum demersum: adaptive plant ecophysiology, biochemistry and molecular toxicology. Brazilian Journal of Plant Physiology 17(1):3-20.

Aravind P, Prasad MNV (2005a). Modulation of cadmium-induced oxidative stress in Ceratophyllum demersum by zinc involves ascorbate-glutathione cycle and glutathione metabolism. Plant Physiology and Biochemistry 43(2):107-116.

Beauchamp C, Fridovich I (1971). Superoxide dismutase: Improved assays and an assay applicable to acrylamide gels. Analytical Biochemistry 44(1):276-287.

Benkeblia N (2005). Free radical scavenging capacity and antioxidant properties of some selected onion (Allium cepa L.) and garlic (Allium sativum L.) extracts. Brazilian Archives of Biology and

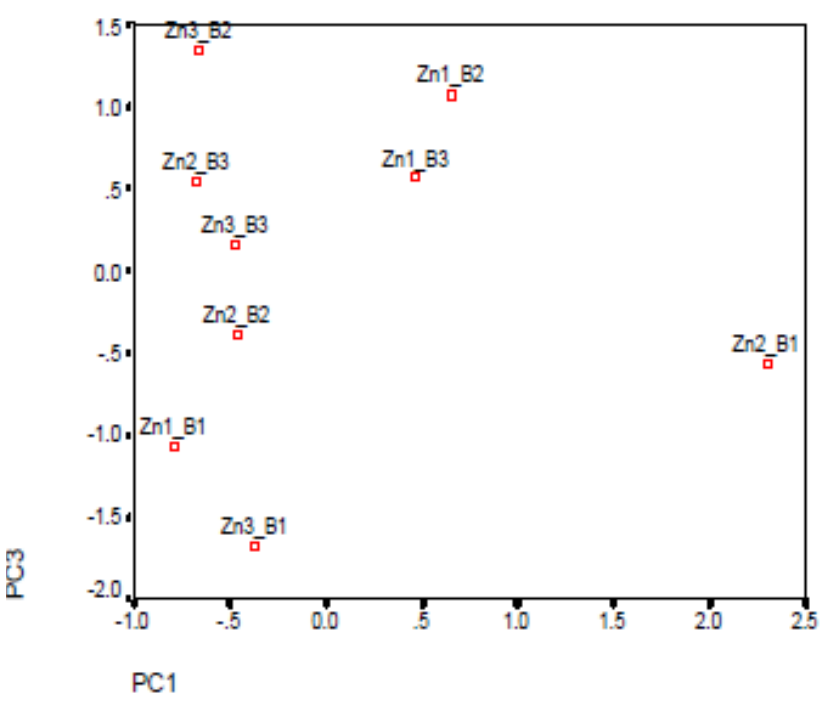

Fig. 2. Scatter diagram of the regression factor scores for the first and third components produced by PCA

Technology 48(5):753-759.

Bhattacharya A, Chattopadhyay A, Muzumdar D, Chakravarty A, Pal $S$ (2010). Antioxidant constituents and enzyme activities in chilli pepper. International Journal of Vegetable Science 16(3):201211.

Blevins DG, Lukaszewski KM (1998). Boron in plant structure and function. Annual Review of Plant Biology 49:481-500.

Bonnet M, Camares O, Veisseire P (2000). Effects of zinc and influence of Acremonium lolii on growth parameters, chlorophyll a fluorescence and antioxidant enzyme activities of ryegrass (Lolium perene L. cv. Apollo). Journal of Experimental Botany 51(346):945-953.

Braca A, Tommasi ND, Di-Bary L, Pizza C, Polifi M, Morelli I (2001). Antioxidant principles from Baubinia terapotensis. Journal of Natural Products 64(7):892-895.

Cakmak I (2000). Tansley Review No. 111. Possible roles of zinc in protecting plant cells from damage by reactive oxygen species. New Phytologist 146:185-205.

Cakmak I, Kurz H, Marschner H (1995). Short-term effects of boron, germanium and high light intensity on membrane permeability in boron deficient leaves of sunflower. Physiologia Plantarum 95(1):11-18.

Camacho CJJ, Anzelotti D, González FA (2002). Changes in phenolic metabolism of tobacco plants during short-term boron deficiency. Plant Physiology Biochemistry 40:997-1002.

Camacho CJJ, Lunar L, Lafont F, Baumert A, González FA (2004). Boron deficiency causes accumulation of chlorogenic acid and caffeoyl polyamine conjugates in tobacco leaves. Journal of Plant Physiology 161:879-881.

Casanas R, Gonzalez M, Rodriguez E, Marrero A, Diaz C (2002). Chemometric studies of chemical compounds in five cultivars of potatoes from Tenerife. Journal of Agricultural and Food Chemistry 50(7):2076-2082.

Cervilla LM, Blasco B, Rios JJ, Romero L, Ruiz JM (2007). Oxidative stress and antioxidants in tomato (Solonum lycopersicum) plants 
subjected to boron toxicity. Annals of Botany 100(4):747-756.

Chaoui A, Mazhoudi S, Ghorbal MH, Ferjani EE (1997). Cadmium and zinc induction of lipid peroxidation and effects on antioxidant enzyme activities in bean (Phaseolus vulgaris L.). Plant Science 127(2):139-147.

Cuypers A, Vangronsveld J, Clijsters H (2002). Peroxidases in roots and primary leaves of Phaseolus vulgaris copper and zinc phytotoxicity: a comparison. Journal of Plant Physiology 159:869876.

del Rio LA, Sevilla F, Sandalio LM, Palma JM (1991). Nutritional effect and expression of SODs: induction and gene expression; diagnostics; prospective protection against oxygen toxicity. Free Radical Research Communication 13(1):819-827.

Denre M, Pal S, Chattapadhyay A, Mazumdar D, Chakravarty A, Bhattacharya A. (2011). Antioxidants and pungency of onion. International Journal of Vegetable Science 17(3):233-245.

Dhindsa RS, Tlumb-Dhindsa P, Thorpe TA (1981). Leaf senescence correlated with increased level of membrane permeability and lipid peroxidation and decreased level of superoxide dismutase and catalase. Journal of Experimental Botany 32(1):93-101.

Di Matteo V, Esposito E (2003). Biochemical and therapeutic effects of antioxidants in the treatment of Alzheimer's disease, Parkinson's disease, and amyotrophic lateral sclerosis. Current Drug Targets CNS and Neurological Disorders 2(2):95-107.

Dordas C, Brown PH (2005). Boron deficiency affects cell viability, phenolics leakage and oxidative burst in rose cell cultures. Plant Soil 268:293-301.

Dube BK, Sinha P, Chatterjee C (2000). Boron stress affects metabolism and seed quality of sunflower. Tropical Agriculture 77(2):89-92.

Garber, SL, Rintala DH, Holmes SA, Rodriguez GP, Friedman J (2002). A structured educational model to improve pressure ulcer prevention knowledge in veterans with spinal cord dysfunction. Journal of Rehabilitation Research and Development 39(5):575588.

Garcia POC, Rivero RM, Lopez-Lefebre LR, Sanchez E, Ruiz JM, Romero L (2001). Response of oxidative stress metabolism to the application of carbendazin plus boron in tobacco. Functional Plant Biology 28(8):801-806.

Govindan PR (1950). A note on the influence of boron on the yield and ascorbic acid content in the tomato fruit. Current Science 19(10):319.

Gunes A, Soylemezoglu G, Inal A, Bagci EG, Coban S, Sahin O (2006). Antioxidant and stomatal responses of grapevine (Vitis vinifera L.) to boron toxicity. Scientia Horticulturae 110(3):279284.

Hajiboland R, Amirazad H (2010). Drought tolerance in Zndeficient red cabbage (Brassica oleracea L. var. capitata f. rubra) plants. Horticulture Sciences 37(3):88-98.

Kar M, Mishra D (1976). Catalase, peroxidase, and polyphenoloxidase activities during rice leaf senescence. Plant Physiology 57(2):315-319.

Karioti A, Chatzopoulou A, Bilia AR, Liakopoulos G, Stavrianakou S, Skaltsa H (2006). Novel secoiridoid glucosides in Olea europaea leaves suffering from boron deficiency. Bioscience, Biotechnology and Biochemistry 70(8):1898-1903.

Keles Y, Öncel I, Yenice N (2004). Relationship between boron content and antioxidant compounds in Citrus leaves taken from fields with different water source. Plant and Soil 265(1-2):345353.

Kosesakal T, Unal M (2009). Role of Zinc deficiency in photosynthetic pigments and peroxidase activity of tomato seedlings. IUFS Journal of Biology 68(2):113-120.

Luaszewski KM, Blevins DG (1996). Root growth inhibition in boron deficient and Aluminium stressed squash may be a result of ascorbate metabolism. Plant Physiology 112(3):1135-1140.

Luo ZB, He XJ, Chen L, Tang L, Gao S, Chen F (2010). Effects of zinc on growth and antioxidant responses in Jatropha curcas seedlings. International Journal of Agricultural Biology 12:119124.

MarschnerH (1995). Mineral Nutrition of Higher Plants, 2nd Ed. Academic Press, San Diego, pp 379-396.

Molassiotis A, Sotiropoulos T, Tanou G, Diamantidis G, Therios I (2006). Boron induced oxidative damage and antioxidant and nucleolytic responses in shoot tips culture of the apple rootstock EM9 (Malus domestica Borkh). Environmental and Experimental Botany 56(1):54-62.

Mondy NI, Munshi CB (1993). Effect of boron on enzymetic discoloration and phenolic and ascorbic acid contents of potatoes. Journal of Agricultural and Food Chemistry 41(4):554-558.

Pfeffer H, Dannel F, Römheld V (1998). Are there connections between phenol metabolism, ascorbate metabolism and membrane integrity in leaves of boron deficient sunflower plants? Physiologia Plantarum 104(3):479-485.

Prieto P, Pineda M, Aguilar M (1999). Spectrophotometric quantitation of antioxidant capacity through the formation of a phosphomolybdenum complex: Specific application to the determination of vitamin E. Analytical Biochemistry 269(2):337341.

Rout GR, Das P (2003). Effect of metal toxicity on plant growth and metabolism. Agronomie 23:3-11.

Ruiz JM, Bretones G, Baghour M, Ragala L, Belakbir A, Romero L (1998b). Relationship between boron and phenolic metabolism in tobacco leaves. Phytochemistry 48(2):269-272.

Schwimmer S, Weston WJ (1961). Enzymatic development of pyruvic acid in onion as a measure of pungency. Journal of Agricultural and Food Chemistry 9(4):301-304.

Vinson JA, Hao Y, Su X, Zubik L (1995). Phenol antioxidant quantity and quality in foods: vegetables. Journal of Agricultural and Food Chemistry 46(9):3630-3634.

Weckx JEJ, Clijsters HMM (1997). Zn phytotoxicity induces oxidative stress in primary leaves of Phaseolus vulgaris L.) Plant Physiology and Biochemistry 35(5):405-410. 